ADALAH : Buletin Hukum \& Keadilan

Buletin Hukum \& Keadilan

\title{
Hak Konstitusional Warga Negara Dalam Beragama
}

\author{
Nur Rohim Yunus*
}

Agama-agama resmi di Indonesia dijamin keberadaannya oleh negara dengan adanya regulasi UndangUndang Nomor 1/PNPS/1965 tentang Pencegahan Penyalahgunaan Dan/Atau Penodaan Agama. Namun anehnya masih ada beberapa kelompok yang ingin menghapuskan sebagian atau keseluruhan dari isi undang-undang tersebut. Seperti misalnya Musdah Mulia bersama 7 LSM yang pernah mengajukan Judicial Review terkait Undang-Undang Nomor 1/ PNPS/1965 tersebut, sehingga kemudian menimbulkan pro dan kontra di tengah masyarakat. Salah satu dasar gugatannya diantaranya adanya ketidakpastian hukum, sehingga dianggap menjadi alat penekan kelompok mayoritas untuk memaksakan kebenaran kepada kelompok minoritas.

Anggapan tersebut terlihat aneh, adanya jaminan perlindungan agama resmi malah dianggap alat penekan kelompok tertentu terhadap kelompok lainnya. Padahal negara Indonesia yang notabene negara multikultural yang memiliki ragam budaya, bangsa, bahasa dan agama telah rukun dan damai dibawah naungan Pancasila yang berdasarkan Ketuhanan Yang Maha

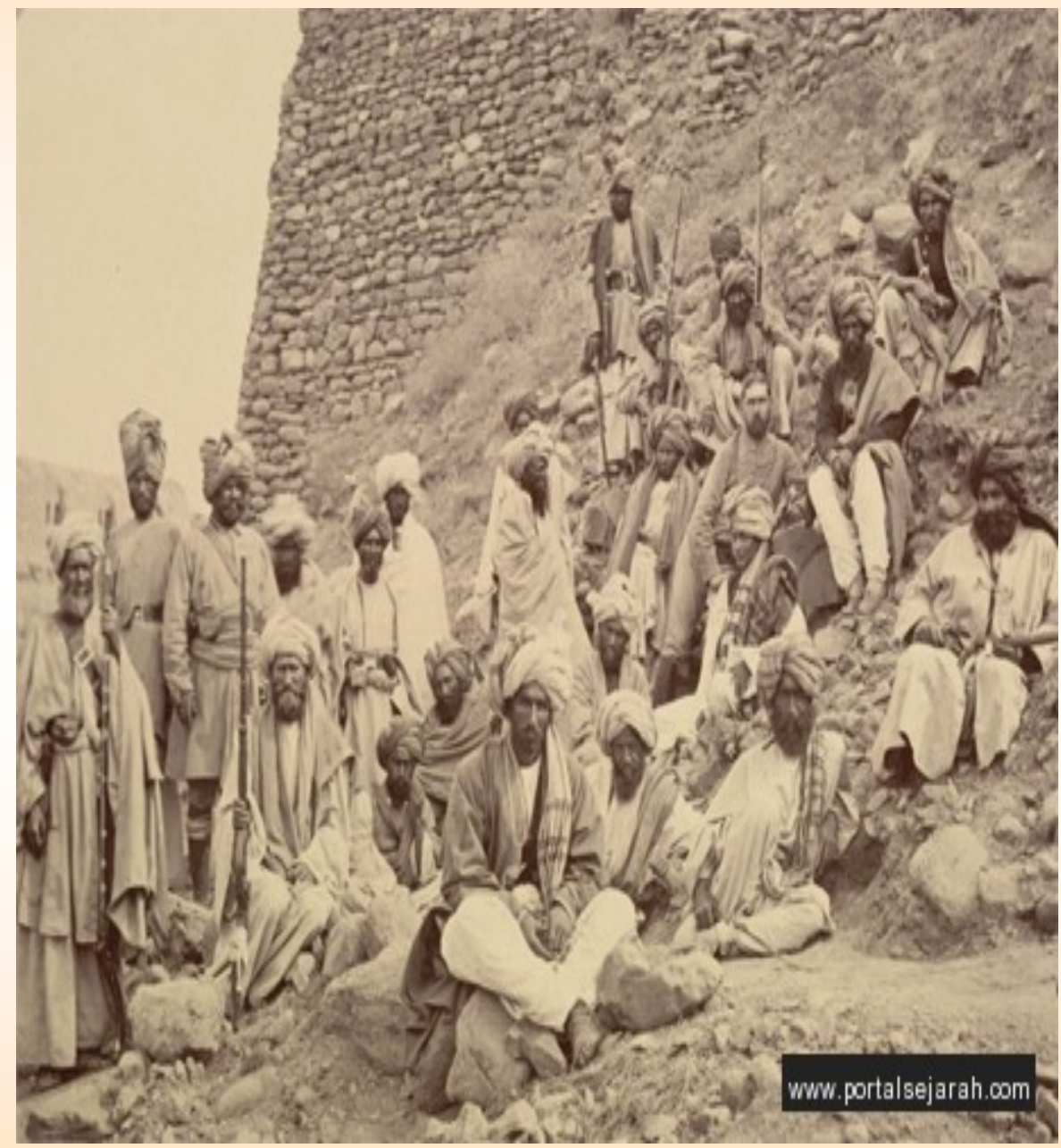

Esa. menuntun warganya untuk berper-

Menurut Yayan Sopyan, masyarakat diberikan hak dan kebebasan untuk memeluk agama dan menjalankan ibadah serta ajaran agamanya masing-masing sesuai dengan kepercayaannya, sebagaimana tertuang dalam amanat konstitusi, selain itu negara pun turut bertanggung jawab dalam meningkatkan ketakwaan dan ilaku mulia. (Yayan Sopyan, 2015 198-199)

Karenanya bila ada wacana kebebasan berekspresi dan kebebasan berpendapat termasuk didalamnya kebebasan untuk menyiarkan keyakinan dan pemahaman keagamaan yang "menyimpang" dan bertentangan dengan 
"mainstream" keyakinan dan pemahaman keagamaan pada umumnya, maka hal itulah pada dasarnya yang merupakan bentuk pelanggaran hak konstitusional warga negara.

Para pemohon dalam pengajuan uji materi UU No. 1/PNPS/1965 berdalih dengan mengatasnamakan Hak Asasi Manusia (HAM) dalam hal kebebasan beragama dan berkeyakinan. Sehingga hal tersebut tanpa sadar malah melupakan hak asasi pemeluk agama resmi yang diakui negara. Hal tersebut diulas Sodikin dalam makalahnya sebagaimana berikut: (Sodikin, 2013: 179).

\section{"Realitas menunjukkan berbagai peristiwa yang mengatasnamakan Hak} Asasi Manusia (HAM) dalam bidang keagamaan yang belakangan ini muncul. Hak kebebasan beragama ini dijadikan alasan untuk secara bebas menganut kepercayaan apa saja dan membuat aliran kepercayaan sendiri tanpa

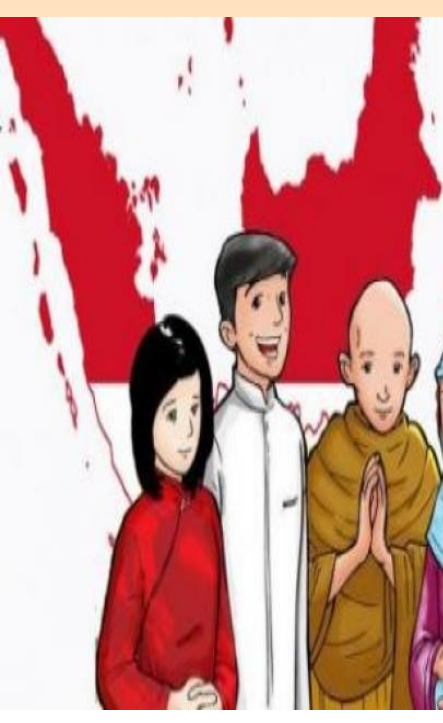
juga memperhatikan hak beragama orang lain."

Secara sederhana seolah perlindungan agama resmi dan pelarangan aliran kepercayaan baru bertentangan dengan Hak Asasi Manusia untuk berekspresi dan berkeyakinan, sehingga kemudian dianggap bertentangan dengan hak konstitusional warga negara. Artinya kelompok pemohon dalam uji materi undangundang ini ingin memberikan ruang bebas seluasluasnya kepada seluruh warga negara Indonesia untuk memeluk agama, keyakinan dan kepercayaan apa saja walaupun bertentangan dengan agama resmi yang diakui negara. Sehingga kebebasan yang diberikan akan menghilangkan perlindungan atas kemurnian agama resmi yang sudah ada. Maka kemudian memungkinkan munculnya sempalan-sempalan aliran yang mirip dengan agama Islam, agama Katolik, agama Kristen, agama Hindu, agama Budha, dan agama Konghucu.
Bila hal ini dibiarkan, tidak menutup kemungkinan agama resmi yang sudah diakui negara tadi akan pudar keasliannya, dan secara tidak langsung hak konstitusional warga negara untuk memeluk agamanya akan terlanggar.

Menurut penulis, pemahaman akan Hak Asasi Manusia dalam memeluk agama yang diusung oleh kelompok pemohon uji materi UU No. 1/PNPS/1965 tidaklah relevan dalam konteks keindonesiaan. Karena filosofi dari HAM itu sendiri tidak lain memberikan kewajiban kepada seseorang untuk menghormati hak

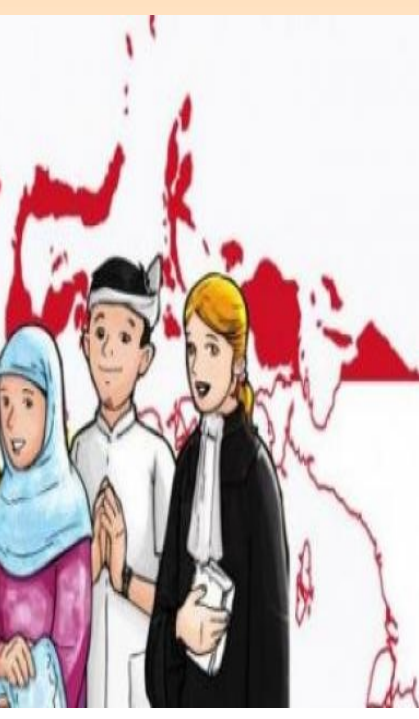
asasi orang lain. Artinya ada kewajiban menghormati agama yang sudah ada diatas tuntutan hak untuk membuat inovasi agama baru.

Pengakuan adanya hak asasi pada seseorang berarti mengakui adanya kewajiban yang harus dilakukan terhadap orang lain artinya adanya kewajiban asasi semua orang untuk menghormati hak asasi yang dimiliki oleh orang lain. Dengan demikian, hubungan antara hak dan kewajiban adalah resiprokal yang harmonis, karena pengakuan hak pada pihak tertentu berimplikasi kewajiban pada pihak lain. []

\section{Daftar Pustaka:}

*Sekjen Pusat Studi Konstitusi dan Legislasi Nasional (POSKO-LEGNAS), UIN Syarif Hidayatullah Jakarta.

Sopyan, Yayan. "Menyoal Kebebasan Beragama dan Penodaan Agama Di Indonesia." JURNAL CITA HUKUM 3, no. 2 (2015).

Sodikin. "Hukum dan Kebebasan Beragama." JURNAL CITA HUKUM 1, no. 2 (2013).

'Adalah; Buletin Hukum dan Keadilan merupakan berkala ilmiah yang diterbitkan oleh Pusat Studi Konstitusi dan Legislasi Nasional (POSKO-LEGNAS), Fakultas Syariah dan Hukum UIN Syarif Hidayatullah Jakarta.

Penasehat: Prof. Dr. H. Abdul Ghani Abdullah, SH., Prof. Dr. H. A Salman Maggalatung, SH., MH. Pemimpin Redaktur: Indra Rahmatullah, Tim Redaktur: Nur Rohim Yunus, Fathuddin, Mara Sutan Rambe, Muhammad Ishar Helmi, Erwin Hikmatiar. Penyunting: Indah Furba, Hasin Abdullah. Setting \& Layout: Siti Anisaul Kamilah. 